Medicine Updates

Faculty of medicine

January 2021, volume 4, issue 4 https://muj.journals.ekb.eg

dean@med.psu.edu.eg

vice_dean_postgraduate@med.psu.edu.eg

DOI:10.21608/muj.2020. 42837.1029

\title{
" Implementation of quality Tools to prevent patient fall morbidity and mortality risks in EL -TADAMON HOSPITAL"
}

DR. Hany Mohamed Abd Rauf

Ph. Eman Hassan Sheta

Ph. Rania Elsayed Ibrahim ..

Ph. May Ahmed Abozekry. .
Health care quality

Health care quality

Health care quality

Health care quality.

Ph. Ghada ALaa EL din Abd Elmonaem Health care quality

Ph. Noha Ibrahim Eldesouky

Health care quality

Ph. Amiera Elsaid Rakha

Health care quality

Mrs. Sabreen Ahmed Mohamed

Health care quality

Mrs. Heba sedek saad eldin

Health care quality

\section{$\underline{\text { Abstract }}$}

Patient fall is: "an event which results in a person coming to lower level or rest suddenly on the ground ".

Fall events which lead to death are considered one of the top ten reportable sentinel events in health care organizations. 
Health care organizations should develop an effective fall preventive program due to increasing of fall events and cost to treat fall injuries in hospitals

This study demonstrated an effective implementation of quality tools to reduce Patient falls morbidity and mortality risks.

\section{METHODS:}

- FOCUS PDCA

- , Action plan

- Cause \&effect (fish bone analysis)

- Flow chart

- Check list

RESULTS :Number OF patient fall decreased after implementation of assessment tools

andincrease Patient and family education about fall prevention

\section{Conclusion :-Patient safety comes first.}

-The aim of patient safety standards as fall prevention is to prevent additional harm to patients in health care organizations.

-Implementation of policy and procedures for fall prevention keep patient falls down low.

\section{Key words}

\section{-Quality tools -Patient falls $\quad$-Morbidity $\quad$-Mortality}

\section{INTRODUCTION}

Patient falls measure for hospital compliance with patient safety standards .

In the united States, each year 700.000 to 1.000 .000 patient exposed to falls in hospitals, many of this falls lead to serious injuries which increase hospital costs .(Ganz, Huang, \&Saliba, 2013)

There are many risk factors for falls age, physical status and medical conditions which lead to weakness. (The Joint Commision, 2020)

US hospitals falls rate is $3.53 \%$ per 1000 patients days (Bouldin et al .(2013)

Hospital cost for falls injuries exceeds $\$ 30.000$ and these events are preventable, SO according to international and national studies which indicate the increase of patient fall events and its results, we must develop an effective fall preventive program according to quality standards. 


\section{AIM OF THE STUDY}

The following intended outcomes will be fulfilled by the endof this research:

-Establishment of quality standards tools to prevent patient fall events.

-Application of awareness campaign in ELTADAMON hospital to ensure patient safety. -Improve coordination of all hospital staff for fall risk reduction activities.

\section{Methodology}

Quality tools used (TQM TOOLS):

- Cause \&effect diagram (fish bone analysis)

- Flow chart

- Action plan

- Check list

- FOCUS-PDCA

Action plan to reduce patient fall risks

It should be clear.

It should be realistic.

It should doable.

Has timeline (starting and ending time).

It must be complete.

Flow chart :

- Allow all health care team to flow sequence of events in the process of services .

- Show unexpected complexity,problems areas

- Compares and contrasts the actual VS the idea flow to identify improvement opportunist.

- Allow teams to come to an agreement

- Identifies location where additional data are needed

- Servese as training aid for understanding and completing the process.

Measuring Progress Checklist

This Checklist can be used to monitor progress fall prevention efforts.

the checklist should be completed by The Implementation Team leader 
This tool can be used to ensure that there is not skipped any essential steps in fall prevention efforts.

\section{Results}

This study included many quality tools to have solution for decreasing fall risk

Fish bone analysis :(figure 1)
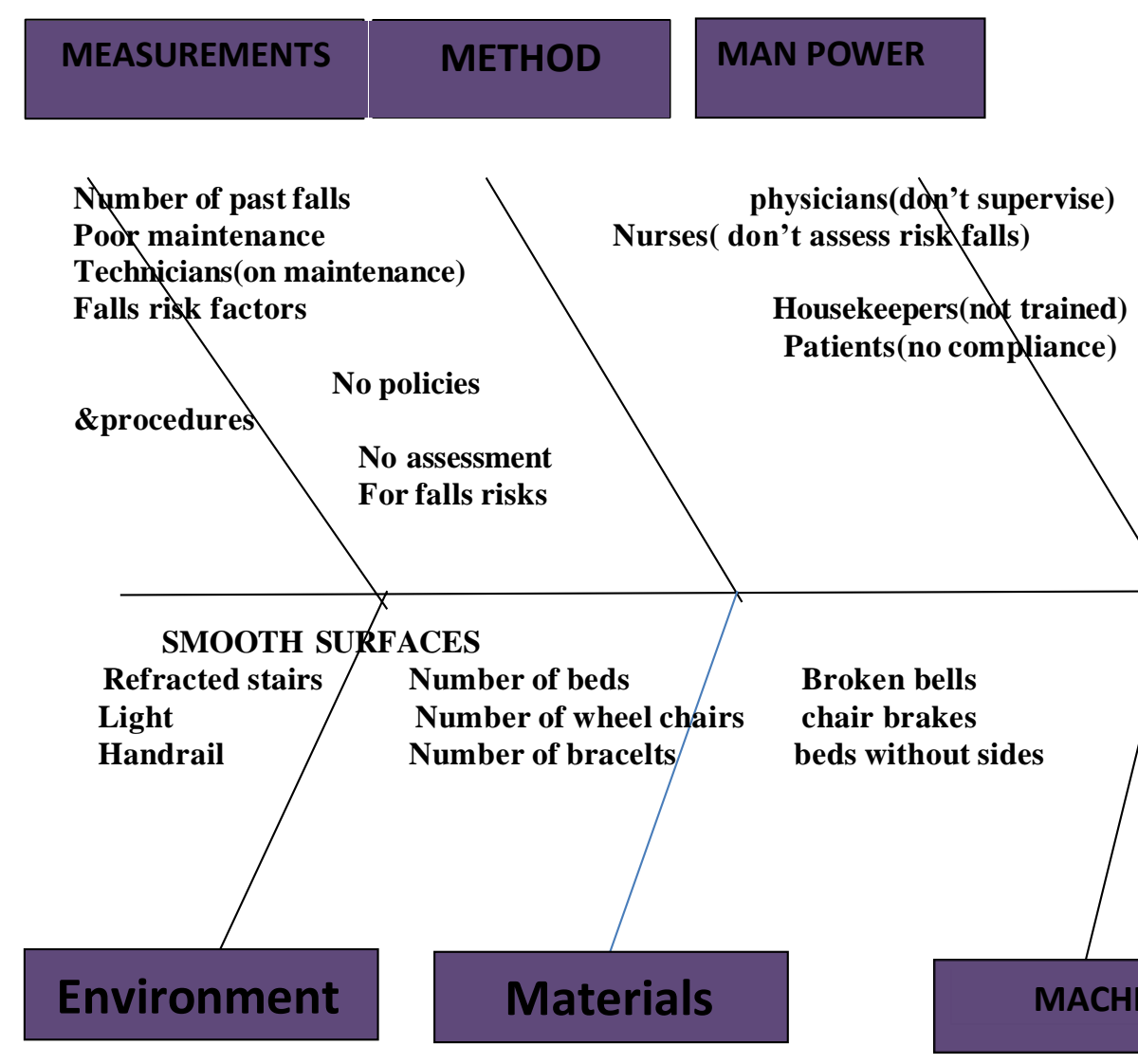

\section{ACES}

Number of beds

Number of wheel chairs

Number of bracelts

$$
\text { Patients(no compliance) }
$$

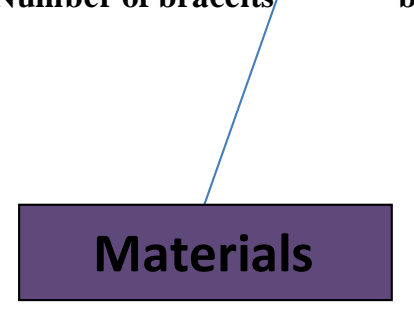

chair brakes

beds without sides

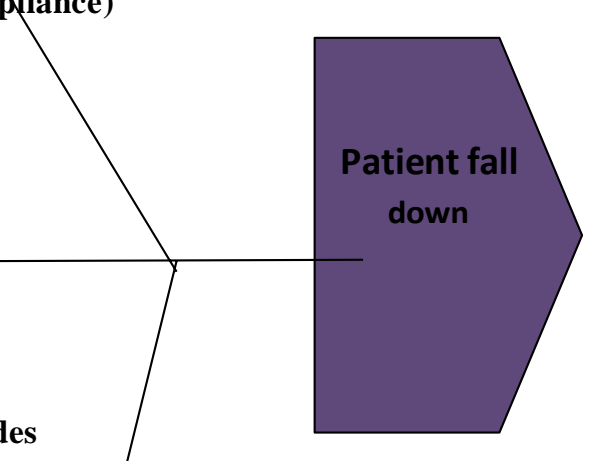

FISHBONE(CAUSE\&EFFCTS DIAGRAM)

FISHBONE(CAUSE\&EFFCTS DIAGRAM) indicates root causes of patient falls: -Patient non-compliance with instructions

-Nurses don't make assessment for patient falls risks

-Physicians don't supervise assessment.

Technicians don't maintain (chair wheels/beds/chair brakes).

-Lack of training of Housekeepers 
- Methods:

There are no policies and procedures for assessment patient fall risks or there is no implementation for policies

\section{- Measurement}

- Number of past fall for each patient

- Training about fall risk factors

- Machine:broken bells ,chair brakes,beds without sides

- Material :number of bed without sides ,number of wheel chair, number of bracelets

- Environment :smooth surfaces, light ,refracted stairs

\section{Flow chart : (figure 2)}

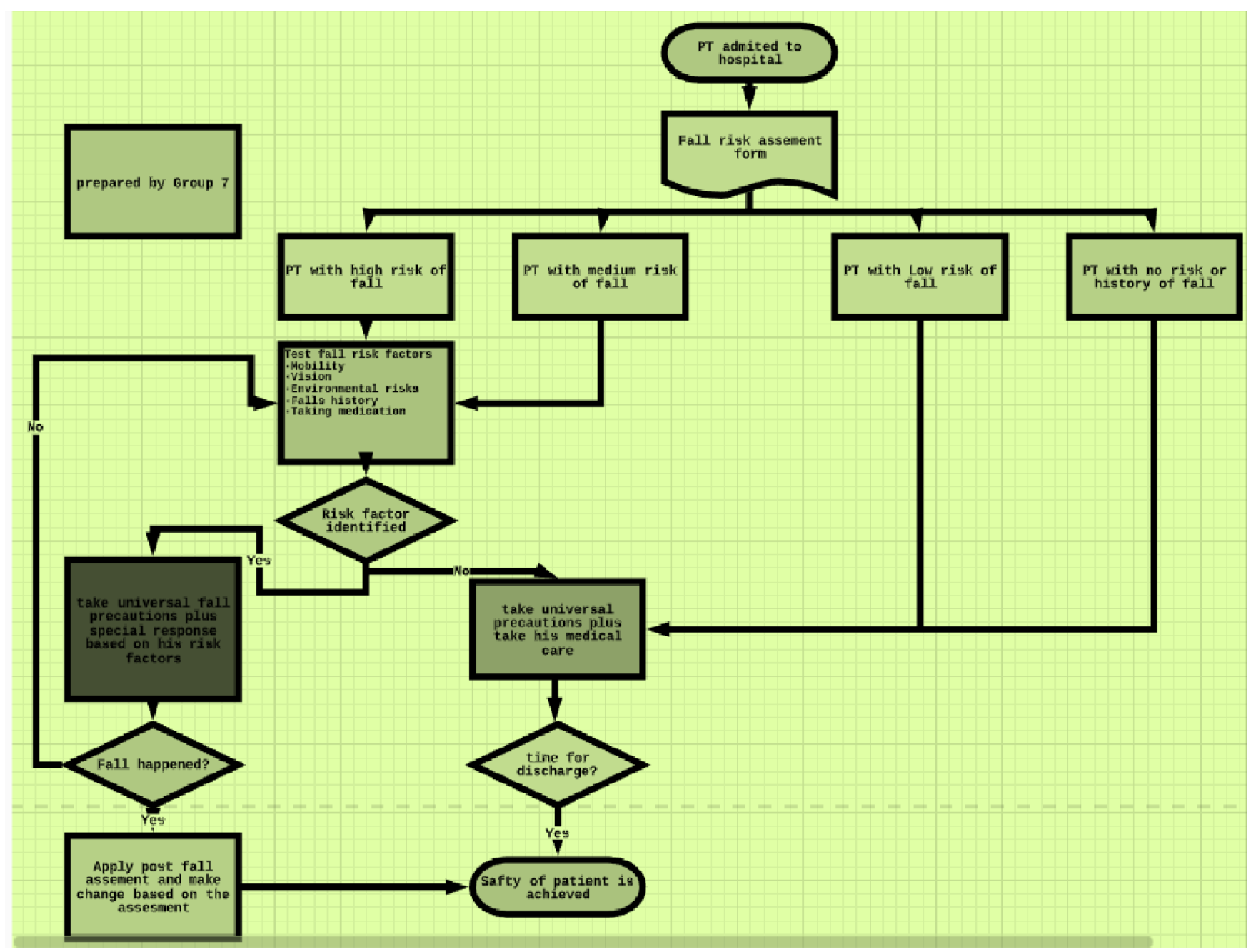

Figure(2):Flow chart indicates patient flow at hospitals 
In patient with no risk or history of fall and patients with low risk fall take universal precaution plus taking medical care

Patient with medium or high risk of fall, risk factor must be identified and must take universal precaution till discharge.

\section{Action plan}

we can decrease patient fall by

Continuous training for health care staff

Using AHRQ definition to report falls

Using fall risk assessment tools

Analysis outcome data to monitor policies and procedures

\section{:( table 1)}

\section{Checklist:}

Monitoring patient fall by monitoring items in the checklist

\section{:( table2)}

\section{Discussion}

This study demonstrated an effective implementation of quality tools to reduce Patient falls morbidity and mortality risks.

Falls are common among inpatients so Inpatient fall prevention programs must be applied and updated to reduce falls.

This study indicates that the risk of prevent fall depends on the patient's susceptibility and environmental hazards.

screening can determine whether a person has a low or high risk of falls and assessment of risk can inform the development of prevention strategies.Currently the National Standards require that all patients have a documented falls risk screen on admission to hospital and on transfer between settings.

In inpatient we use MORSE tool to screening our patient

\section{In outpatient:}

Tools include

\section{MORSE FALLRISK SCALE}

-Schmid Assessment

STRATIFY SCALE 


\section{- Another studies support our study and implement fall prevention programs.}

Northwestern Memorial Hospital (Chicago), a 725 academic medical centers, recently updated the fall prevention program to simplify its approach to fall prevention. All patients are screened for higher than standard fall risk on admission every 24 hours.

Recommendation of standard interventions and good practice for all patients. The training for all managers provided information, materials, and job aids for staff to facilitate good implementation.

A reduced number (36 to 13)of interventions means fall prevention, and important safety measures were to be involved into the patients' plan of care.

\section{The JOINT COMMISSION JOURNAL ON QUALITY AND SAFETY}

-Several studies show that we can decress relative risk for falls by as much as $30 \%$ by using multicomponent programs to prevent falls in inpatients.

the updated review is to incress the benefits and achieve acute care settings of fall prevention Programs and to identify factors associated with successful implementation of the programs. The conclusions of the existing meta-analysis supported two new ,randomized,controlled trials. We did not systematically examined harms, but potential harms included increased use of restraints and decreased efforts to mobilize patients.successful implementation were associated with the following themes:( leadership support, engagement of staff in program design, guidance of the prevention program by a multidisciplinary committee, testing interventions, use of information technology systems to provide data, staff education and training, and changes in attitudes about fall prevention).

\section{Conclusion}

From the results of this research it is included that:-

\section{-Patient safety comes first.}

-The goal of patient safety programes is to prevent additional harm to patients while they are hospitalizedlike fall prevention

-Implementation of policy and procedures for fall prevention keep patient falls down low.

-Assessment of risk can inform the development of prevention strategies and Screening can determine if a person has a low or high risk of falls and -By applying quality tools in this study and determination of root causes can decrease the patient fall risk. 
We can learn more about factors contributing to falls, byimprove communication and learning about fall risk within and across units using increase reporting of assisted falls and decrease rate of injurious falls.

\section{Recommendation}

From the results of this research it is recommended that:

- IT should implement patient fall prevention policy \& procedures.

- It should put valid and reliable tools.

- It should Train staff to use risk assessment tools.

- It shouldassessand screen all patients.

- It should increase Patient and family education about fall prevention.

- It should improve communication between pharmacy and medical wards for receiving the medication $\&$ giving advice for the best time to give medication.

- It should encourage reporting for all health care providers

- It should analyze the cause of incident (fall) to be done by the Quality nurse.

- It should increase Training and education for nurses in nursing education department.

- It should develop education \& training session for house keeper

\section{References}

- Agency for Healthcare Research and Quality. (2019). Falls.U.S. Department of Healthcare Research and Quality. Retrieved from https://bit.ly/2KuOCKY

- Barker A, Kamar J, Graco M, Lawlor V, Hill K. Adding value to the STRATIFY falls risk assessment in acute hospitals. Journal of Advanced Nursing. 2011;67:450-7.

- Becker's Hospital Review. (2013). 5 Proven Strategies to Prevent Patient Falls. Retrieved from https://bit.ly/2Z28SYC

- (Bouldin et al .(2013)

- Centers for Medicare and Medicaid Services. (2019). Hospital-Acquired Conditions (Present on Admission Indicator). Retrieved from https://go.cms.gov/30cgRUm

- (Ganz, Huang, \&Saliba, 2013)

○ Haines, T.P., Bennell, K.L., Osborne, R.H., Hill K.D. (2004). Effectiveness of targeted falls prevention programme in subacute hospital setting: randomised controlled trial. BMJ. Retrieved from https://bit.ly/2N0xxtZ

- Mellisa J.Kraus,2004

- Stapleton, C., et al., Four-item fall risk screening tool for subacute and residential aged care: The first step in fall prevention. Australasian Journal on Ageing, 2009. 28(3): p. 139-143.

- (The Joint Commision, 2020)

- The JOINT COMMISSION JOURNAL ON QUALITY AND SAFETY 
(Table 1) indicate action plan to prevent patient fall risks

\begin{tabular}{|c|c|c|c|c|c|c|}
\hline \multirow{7}{*}{$\begin{array}{l}\text { Goal } \\
\text { Increas } \\
\text { e } \\
\text { patient } \\
\text { safety } \\
\text { Reducti } \\
\text { on of } \\
\text { patient } \\
\text { fall } \\
\text { risks }\end{array}$} & Obejectives & Activities & TE AM & WHEN & Kpi & Budget \\
\hline & $\begin{array}{c}\text { Forming a } \\
\text { multidescipliry team } \\
\text { of } \\
\text { nursing, pharm acy, } \\
\text { physical therapy, and } \\
\text { quality improv ement } \\
\text { that is } \\
\text { a ccoun table for } \\
\text { outcomes of fall risk } \\
\text { reduction program }\end{array}$ & $\begin{array}{c}\text {-continuous training } \\
\text { for all health care sta ff } \\
\text {-provid e A ssessm ent } \\
\text { tools. } \\
\text { M orse Fall Scale } \\
\text { HUMTY-DUMTY } \\
\text { *Bracelts. } \\
\text { *red so cksforhigh risk } \\
\text { patients. } \\
\text { *Bed alarms } \\
\text { *Mobility aids. } \\
\text { * Ma fe footwear. } \\
\text { *Hip protector }\end{array}$ & $\begin{array}{l}\text { ALL health } \\
\text { care staff } \\
\text { responsible } \\
\text { for patient } \\
\text { safety: } \\
\text { Physicians } \\
\text { Nurses } \\
\text { Pharma cists } \\
\text { Employees } \\
\text { Patient } \\
\text { him/her self } \\
\text { Patient } \\
\text { relatives } \\
\text { caregiv ers }\end{array}$ & $\begin{array}{c}\text { 3- } \\
\text { 6mont } \\
\text { hs }\end{array}$ & $\begin{array}{l}\text { NUMBE R } \\
\text { OF } \\
\text { OVR FOR } \\
\text { FALL } \\
\text { INCIDE NT } \\
\text { S } \\
\text { NUMBE R } \\
\text { OF } \\
\text { INJURIES }\end{array}$ & $\begin{array}{l}200000 \\
\text { E.P }\end{array}$ \\
\hline & $\begin{array}{c}\text { Inhance reporting of } \\
\text { falls, get } \\
\text { more information } \\
\text { about factors } \\
\text { contributing to falls, } \\
\text { injurious falls rate } \\
\text { decreased }\end{array}$ & $\begin{array}{l}\text { Use AHRQ } \\
\text { d ef inition of a fall } \\
\text { to report falls }\end{array}$ & $\begin{array}{l}\text { ALL health } \\
\text { care staff }\end{array}$ & & & \\
\hline & $\begin{array}{c}\text { fall p redicted } \\
\text { accurately, } \\
\text { Highestrisk of falls } \\
\text { patients is targeted } \\
\text { for direct } \\
\text { interv entions } \\
\text { accurracy and } \\
\text { sp ecificity of the tool is } \\
\text { calulatedin } \\
\text { your hospital }\end{array}$ & $\begin{array}{c}\text { Nurses u sevalid } \\
\text { fall risk } \\
\text { a ssessment tool }\end{array}$ & Nurses & & & \\
\hline & $\begin{array}{c}\text { Implement reliable } \\
\text { universal } \\
\text { interventions to } \\
\text { decrease risk of } \\
\text { patients falls }\end{array}$ & & & & & \\
\hline & $\begin{array}{c}\text { Imp lem ent relible } \\
\text { targeted } \\
\text { interventions to } \\
\text { decrea se risk of } \\
\text { patients falls } \\
\end{array}$ & & & & & \\
\hline & $\begin{array}{l}\text { Staff communication } \\
\text { improvem ent and } \\
\text { learning about fall } \\
\text { risk }\end{array}$ & & & & & \\
\hline
\end{tabular}

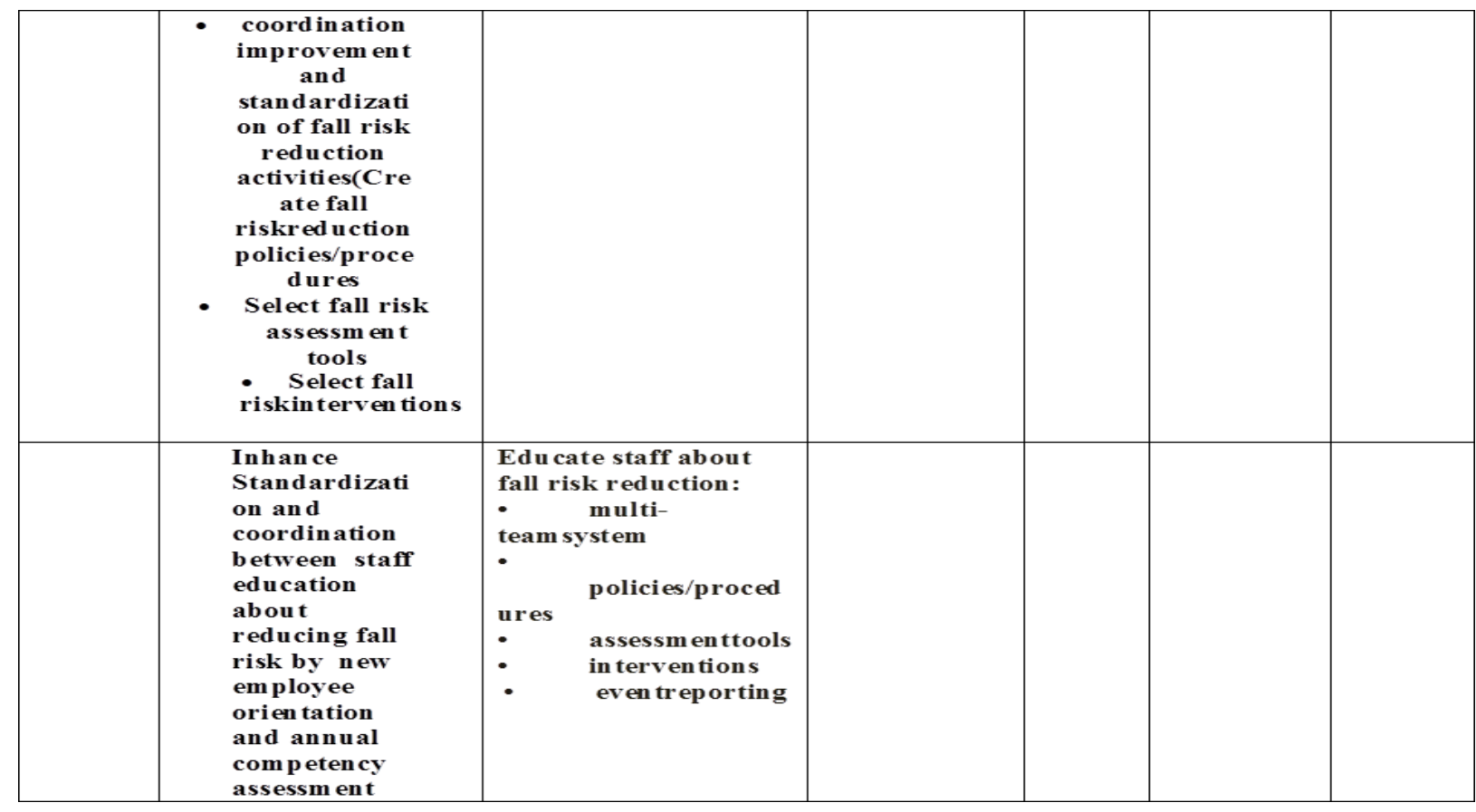


( Table 3)Measuring Progress Checklist

\begin{tabular}{|c|l|l|l|l|}
\hline observation & yes & no & N/A & COMMENTS \\
\hline $\begin{array}{c}\text { Measuring fall rates } \\
\text { known by staff } \\
\text { definition fall and injurious fall is } \\
\text { falls }\end{array}$ & & & & \\
\hline $\begin{array}{c}\text { Inhance rewards culture reporting of } \\
\text { Fall rates are collected and analyzied } \\
\text { preferably monthly }\end{array}$ & & & & \\
\hline $\begin{array}{c}\text { monitoringfall ratesevery 3month, } \\
\text { Measuring key processes of care }\end{array}$ & & & & \\
\hline $\begin{array}{c}\text { ALL PATIENT SCREENED } \\
\text { ALL INPATIENT SCREENED }\end{array}$ & & & & \\
\hline $\begin{array}{c}\text { All patients areassessed for fall risk } \\
\text { within 24 hours of admission }\end{array}$ & & & & \\
\hline $\begin{array}{c}\text { Development and implementation of } \\
\text { care plan addressing every deficit on } \\
\text { fall risk assessment }\end{array}$ & & & & \\
\hline
\end{tabular}




\section{ut Plan To Do Actions}

tool used is Gantt Chart

\begin{tabular}{|c|c|c|c|c|c|}
\hline Solution & Method & Target & Time frame & Responsible & Resource \\
\hline $\begin{array}{l}\text { Implementation of } \\
\text { fall down } \\
\text { reduction or } \\
\text { prevention policy } \\
\& \text { procedures }\end{array}$ & $\begin{array}{l}\text { Meeting, } \\
\text { Lectures, } \\
\text { Observation, } \\
\text { Checking } \\
\text { Assessment } \\
\text { Form }\end{array}$ & $100 \%$ & & $\begin{array}{l}\text { Nursing } \\
\text { Director }\end{array}$ & \\
\hline $\begin{array}{l}\text { Housekeeping } \\
\text { Training }\end{array}$ & $\begin{array}{l}\text { Lectures, } \\
\text { workshops }\end{array}$ & $100 \%$ & & $\begin{array}{l}\text { Housekeeping } \\
\text { Supervisor }\end{array}$ & \\
\hline $\begin{array}{l}\text { Warning signs } \\
\text { supply }\end{array}$ & Purchase & $100 \%$ & & $\begin{array}{l}\text { Property } \\
\text { Control }\end{array}$ & \\
\hline $\begin{array}{l}\text { Patient \& family } \\
\text { education }\end{array}$ & $\begin{array}{l}\text { Lectures } \\
\text {,Posters, } \\
\text { Workshops }\end{array}$ & $100 \%$ & & $\begin{array}{l}\text { Patient \& } \\
\text { Family } \\
\text { Education }\end{array}$ & \\
\hline $\begin{array}{l}\text { Develop policy \& } \\
\text { procedures for } \\
\text { follow up patient } \\
\text { medication(for } \\
\text { patient at risk of } \\
\text { falls) }\end{array}$ & & $100 \%$ & & $\begin{array}{l}\text { Pharmacy } \\
\text { Director }\end{array}$ & \\
\hline \multicolumn{6}{|c|}{ Do The Improvement, Collect \& Analyze Data } \\
\hline \multicolumn{6}{|c|}{$\begin{array}{l}\text { 1. Policy \& procedures for fall prevention is done \& implemented } \\
\text { 2. Warning signs now available } \\
\text { 3. Training for housekeeper done } \\
\text { 4. Policy for follow up medications for pati ent at high-risk to fall done } \\
\text { 5. Improvement in reporting system.(now we are under reporting) }\end{array}$} \\
\hline \multicolumn{6}{|c|}{ Check F or The Results } \\
\hline \multicolumn{6}{|c|}{$\begin{array}{l}\text { 1. Monitoring for implementation of the policy for fall prevention and patient assessment } \\
\text { 2. Last month no report for patient falls down } \\
\text { 3. Encourage the reporting } \\
\text { 4. The floor is dry now after cleaning }\end{array}$} \\
\hline
\end{tabular}

- Encourage reporting for all health care providers

- Analyze the cause of incident (fall) to be done by the Quality nurse.

- Auditing the policy to be done by the Quality nurse.

- Training and education for nurses in nursing education department.

- Check the competencies related to patient fall prevention scale and management by nursing education department. 